\begin{tabular}{|c|c|c|}
\hline & Journal Homepage: - www.journalijar.com & $\begin{array}{l}\text { INTERNATIONAL JOURNAL OF } \\
\text { ADVANCED RESEARCH (IJAR) }\end{array}$ \\
\hline 2320-5407 & $\begin{array}{c}\text { Article DOI: } 10.21474 / \text { IJAR01/2852 } \\
\text { DOI URL: http://dx.doi.org/10.21474/IJAR01/2852 }\end{array}$ & \\
\hline
\end{tabular}

RESEARCH ARTICLE

\title{
PROPERTIES AND APPLICATION OF MICROBIAL TRANSGLUTAMINASE PRODUCED FROM A NEWLY ISOLATED STRAIN OF STREPTOMYCES SP.
}

\author{
Dalia H. Eshra, Samer M. El-Iraki and Taiseer M. Abo Bakr*
}

Food Science and Technology Department, Faculty of Agriculture, El-Shatby, Alexandria University, Alexandria Egypt.

\section{Manuscript Info}

Manuscript History

Received: 25 November 2016

Final Accepted: 30 December 2016

Published: January 2017

Key words:-

Transglutaminase, Streptomyces sp, cross-linking, Shamy bread.

\begin{abstract}
The aim of the present work is to study some physical properties of microbial transglutaminase (MTGase) produced from a newly isolated strain of Streptomyces sp. Also, its application in producing Shamy bread from a mixture of wheat and corn flours was investigated. The results revealed that the enzyme exhibited optimum activity at $45^{\circ} \mathrm{C}$; it retained about $80 \%$ of the initial activity after incubation for one hour at this temperature. The optimum activity was at $\mathrm{pH} 6.5$ and was stable at this $\mathrm{pH}$ for one hour.

The cross-linking effect of the enzyme was tested through cross-linking of wheat dough prepared for Shamy bread. The results indicated that the enzyme have a cross- linking effects towards the free amino and thiol groups of wheat dough. The free amino groups of the wheat dough were $0.538 \mu \mathrm{M} / \mathrm{mg}$ flour without adding the enzyme. It decreased to $0.378 \mu \mathrm{M} / \mathrm{mg}$ flour when treated with the enzyme; the percent of reduction was 29.74. Mixing corn flour with wheat flour decreased the free amino groups of the resulted dough. It decreased to $0.248 \mu \mathrm{M} / \mathrm{mg}$ flour in the sample treated with the enzyme and containing $30 \%$ corn flour with percentage of reduction 34.39.

In general, increasing the percentage of corn flour in the blends treated with MTGase decreases the free thiol groups. The free thiol groups of the wheat dough (without enzyme) were $11.222 \mu \mathrm{M} / \mathrm{g}$ flour, it decreased to $10.342 \mu \mathrm{M} / \mathrm{g}$ flour when treated with the enzyme, with percentage of reduction $7.849 \%$. When the levels of corn flour increased to $30 \%$ the free thiol groups decreased and the percent of the reduction increased to 8.575 . It was noted that the prepared Shamy bread from dough containing $70 \%$ wheat flour and 30\% corn flour and treated with the enzyme have a higher volume with pronounced improvement in the general appearance and quality than that without the enzyme.
\end{abstract}




\section{Introduction:}

Transglutaminase (TGase) ( EC 2.3.2.13) is an enzyme that catalyses an acyl transfer reaction using peptide - bond glutamine residues as acyl doners and several primary amines as acyl acceptors (Yokoyama et al., 2004).

The enzyme is active over a wide range of temperatures and stable between $\mathrm{pH} 5$ and 9 which is the range for most food processing ( Kuraishi et al., 2001). With respect to substrate specificity; most food proteins, legume globulins, wheat, egg yolk and milk caseins, as well as many other albumins could be cross linked by MTGase ( Nonaka et al., 1997).

MTGase is capable of gelling concentrated solutions of proteins such as soybean, milk, beef, chicken and fish proteins. Also, two or more different proteins can be covalently conjugated to produce new proteins with novel functionalities (Nielsen, 1995; Zhu et al., 1995).

The characteristics of MTGase obtained from various microorganisms vary even among strains. MTGase from Streptomyces libani showed slightly lower optimum reaction temperature and thermal stability than from Streptomyces mobaraensis (Umezawa et al., 2002).

The enzyme has many applications in the food industry because its effect of crosslinking which is useful in texturization, foaming and emulsifying properties as well as for improvement of nutritional properties.

Several studies reported that the use of TGase improves baking properties and products quality. The action of enzyme reinforces the protein network structure changing the viscoelastic properties of the dough (Larre et al., 2000). Gerrad et al. (2001) reported that addition the enzyme to dough improved its stability and loaf volume, as well as, improved the lift of puff pastry. Many applications showed that TGase increased the crumb strength of baked loaves and improved the water absorption of the dough, which lowering processing costs for commercial baking (Dube et al., 2007). Ap et al. (2011) reported that the enzyme modified chemical and functional properties of glutenins fraction of proteins, improving dough strength and bread volume. The addition of $1.0 \%$ TGase increased both foam stability and emulsion activity of cake batter. Also, it had the maximum specific volume and the softest texture (Wang et al., 2013).

Corn flour is one of the most valuable cereal flours from a nutritional point of view. However, corn flour is unable to hold gas produced during fermentation for baked products. So, the aim of the present work is to study some physical properties of microbial transglutaminase produced from a newly isolated strain of Streptomyces sp. Also, its application in producing Shamy bread from blends of wheat and high levels from corn flour was investigated.

\section{Materials and Methods:-}

Microorganism:-

The actinomycetes strain used in the present study was isolated from soil samples collected from Alexandria Governorate, Egypt. The strain was identified as Streptomyces diastaticus as reported in the previous paper (Eshra et al., 2015 )

\section{Chemicals and reagents:-}

N-carboxybenzoyl-L-glutaminyl-glycine (CBZwas purchased from Sigma-Aldrich, Co., USA. All the other chemicals were of analytical grade.

\section{Preparation of tryptic casein hydrolyzate (TCH):-}

Twenty grams of alkaline soluble casein were dissolved in $100 \mathrm{ml}$ Tris-buffer $\mathrm{pH} 8.0$, and then $0.2 \mathrm{~g}$ of trypsin (EMerck) were added and incubated for $18 \mathrm{~h}$ at $37^{\circ} \mathrm{C}$. The mixture was boiled for $5 \mathrm{~min}$, cooled in ice bath and centrifuged at $3000 \mathrm{rpm}$ for $20 \mathrm{~min}$ and preserved at $-4^{\circ} \mathrm{C}$. The activity of equal volumes of pure enzyme solution (Ajinomoto Activa WM MTGase) was measured separately by both the prepared TCH and CBZ. A correction factor was calculated to convert the enzyme units measured by TCH to the more common units measured by the synthetic substrate CBZ.The correction factor was measured for each prepared batch of the tryptic casein hydrolyzate. The average of this factor was ranged between 1.42 to 1.55. 


\section{MTGase Activity:-}

The enzyme activity was measured using the colorimetric hydroxamate procedure using TCH and CBZ as substrates. The absorbance was measured at $525 \mathrm{~nm}$ (Spectronic 20, Bausch \& Lomb, USA). One unit of MTGase activity was defined as the amount of enzyme which causes the formation of one micromole of hydroxamic acid per $\min$ at $37^{\circ} \mathrm{C}$. A calibration curve was prepared using $\gamma$-glutamic acid $\gamma$-monohydroxamate (Macedo et al., 2007).

\section{Effect of Temperature:-}

The effect of temperature on the enzyme activity was tested at temperatures ranging from 25 to $60^{\circ} \mathrm{C}$ at $\mathrm{pH}$. The relative activity was determined by maximal activity of the enzyme at a specific temperature as $100 \%$ (Cui et al., 2007).

Thermal stability was determined by incubating the enzyme at 25 to $60^{\circ} \mathrm{C}$ for $1 \mathrm{hr}$. The percentage of stability was determined as follow:

$\%$ stability $=$ Residual units $\times 100 \quad$ (Cui et al., 2007). Initial units

The effect of $\mathrm{pH}$ on the enzyme activity was determined using $50 \mathrm{mM}$ citrate buffer $(\mathrm{pH} 4.0-6.5)$ and $50 \mathrm{mM}$ TrisHCL buffer $\mathrm{pH}$ (7.0-9.0) after $30 \mathrm{~min}$ at $35^{\circ} \mathrm{C}$.To check the $\mathrm{pH}$ stability, the enzyme was incubated with the previous buffers at $37^{\circ} \mathrm{C}$ for $1 \mathrm{hr}$ and the enzyme activity was determined (Cui et al., 2007).

\section{Shamy bread making:-}

Shamy bread was prepared as described by Gujral and Rosell (2004) with some modifications. The following ingredients were used: $500 \mathrm{~g}$ wheat flour (72\% extraction), $450 \mathrm{ml}$ water, $15 \mathrm{~g}$ active dry yeast, $10 \mathrm{~g}$ salt and $40 \mathrm{~g}$ sugar (yeast was previously mixed with sugar and dissolved in $30 \mathrm{ml}$ water). All ingredients were mixed in the Nouval dough mixer (Image, Egypt) for $5 \mathrm{~min}$. MTGase was incorporated at level of 100 units/ $500 \mathrm{~g}$ wheat flour.

The resulted dough was left to ferment for about $20 \mathrm{~min}$ at $30^{\circ} \mathrm{C}$, and then divided into pieces. The pieces were arranged on a wooden board and left to ferment for about $60 \mathrm{~min}$ at the same temperature. The fermented dough pieces were flattened. The flattened loaves were baked at $220^{\circ} \mathrm{C}$ for $5 \mathrm{~min}$ in muffle furance (Vulcan ${ }^{\mathrm{TM}} \mathrm{A}-550$ Yucaipa, California, USA) 10-15 min. The loaves of bread were allowed to cool then packed in polyethylene bags.

The effect of using MTGase on Shamy bread containing different levels of corn flour was studied. Corn flour was added at levels of 10,20,30,40 and 50\% based on the weight of wheat flour. The same method was used for Shamy bread prepared from wheat flour only.

\section{Quantification of free amino groups:-}

Free amino groups in control and MTGase-treated dough samples were determined by the method described by Nielsen et al. (2001). The O-phthaldialdehyde (OPA) $40 \mathrm{mg}$ was dissolved in $1 \mathrm{ml}$ of ethanol. In a separate solution, $1.905 \mathrm{~g}$ of di-sodium tetraborate decahydrate and $50 \mathrm{mg}$ of sodium dodecylsulfate were dissolved in $40 \mathrm{ml}$ of distilled water. The two solutions were mixed and the volume brought to $50 \mathrm{ml}$ with distilled water. The OPA reagent was stored in an opaque bottle in a refrigerator. One part of 2- mercaptoethanol was mixed with 21.27 parts of the OPA reagent just before use in the assay. Supernatant of each sample was obtained by mixing $100 \mathrm{mg}$ dough with $90 \mu \mathrm{l}$ of distilled water, adding $1 \mathrm{ml} 0.1 \mathrm{M} \mathrm{HCl}$, mixing the suspension on a vortex mixer for $10 \mathrm{~min}$ and then centrifuging (Cell Refrigerated Centrifuges, Bunsen) at $16000 \times \mathrm{g}$ for $5 \mathrm{~min}$. To $50 \mu \mathrm{L}$ of the dough supernatant, $250 \mu \mathrm{l}$ of the OPA reagent containing 2-mercaptoethanol was added. Absorbance at $340 \mathrm{~nm}$ was recorded for the mixtures after 2 min using a UV-spectrophotometer (Thermospectronic,UV- visible Spectrophotmeters, Helios). The results were calculated against a serine standard curve (Gujral and Rosell, 2004).

\section{Quantification of free thiol groups:-}

Free thiol groups in control and dough samples -treated with MTGase were determined with a procedure using Ellman's reagent (Rao et al., 2002). Tris-glycine (Tris-Gly) buffer ( $\mathrm{pH} \mathrm{8.0)}$ was prepared by dissolving $10.4 \mathrm{~g}$ Tris, $6.9 \mathrm{~g}$ glycine and $1.2 \mathrm{~g}$ ethylenediamine tetraacetic acid (EDTA) in 11 of distilled water. A solution (GuHCl/ TrisGly) containing $5 \mathrm{M}$ guanidine hydrochloride $(\mathrm{GuHCl})$ in Tris-Gly buffer was prepared. Ellman's reagent contained $4 \mathrm{mg}$ of 5,5' dithiobis-2-nitrobenzoic acid in $1 \mathrm{ml}$ of Tris-Gly buffer $\mathrm{pH}$ 8.0. To obtain supernatant, $200 \mathrm{mg}$ of dough was added to $1 \mathrm{ml}$ of ( $\mathrm{GuHCl} / \mathrm{Tris}-\mathrm{Gly})$ solution, mixed on a vortex mixer for $10 \mathrm{~min}$, and centrifuged (Cell 
Refrigerated Centrifuges, Bunsen) at $16000 \times \mathrm{g}$ for $5 \mathrm{~min}$. (GuHCl/ Tris-Gly) solution $(150 \mu \mathrm{l})$ and Ellman's reagent $(50 \mu \mathrm{l})$ were added to $100 \mu \mathrm{l}$ of the supernatant and the absorbance measured at $412 \mathrm{~nm}$ (Spectronic 20, Bausch \& Lomb, USA). The results were calculated against a cysteine standard curve (Gujral and Rosell, 2004).

\section{Results and Discussion:- Effect of temperature:-}

The results presented in Table (1) indicated that the enzyme exhibited optimum activity at $45^{\circ} \mathrm{C}$. At $60^{\circ} \mathrm{C}, 52.0 \%$ of the maximum enzyme activity was detected. Decreasing the temperature to $25^{\circ} \mathrm{C}$ conserved only $48.0 \%$ of the maximum activity. The enzyme retained about $80 \%$ of the initial activity after incubation for one hour at this temperature. The optimum activity was at $\mathrm{pH} 6.5$ and was stable at this $\mathrm{pH}$ for one hour. Ho et al. (2000) reported that the optimal temperature of TGase enzyme purified from Streptoverticillium ladakanum was $40^{\circ} \mathrm{C}$. It conserved more than $90 \%$ of its activity even after $30 \mathrm{~min}$ incubation at $35^{\circ} \mathrm{C}$. Cui et al. (2007) mentioned that the optimum activity of MTGase from Streptomyces hygroscopicus was at $37-45^{\circ} \mathrm{C}$. Also, they reported that the purified enzyme maintained full activity after incubation for $30 \mathrm{~min}$ at $20^{\circ} \mathrm{C}$. When the temperature was above $50^{\circ} \mathrm{C}$, the enzyme was rapidly inactivated and preserved only $7 \%$ of the initial activity when it was exposed to $60^{\circ} \mathrm{C}$ for $30 \mathrm{~min}$.

Table 1:- Effect of temperature on MTGase activity produced from Streptomyces diastaticus.

\begin{tabular}{|c|c|c|}
\hline Temperature $\left({ }^{\circ} \mathrm{C}\right)$ & Relative Activity $(\%)$ & Stability (\%) \\
\hline 25 & 48.00 & 97.15 \\
\hline 30 & 54.00 & 98.06 \\
\hline 35 & 65.33 & 100.00 \\
\hline 40 & 82.67 & 96.15 \\
\hline 45 & 100.00 & 80.77 \\
\hline 50 & 70.67 & 67.31 \\
\hline 55 & 54.00 & 48.08 \\
\hline 60 & 52.00 & 40.38 \\
\hline
\end{tabular}

\section{Effect of pH:-}

The optimum activity was at $\mathrm{pH}$ 6.5. The activity decreased rapidly at alkaline $\mathrm{pH}$, but it decreased gradually at acidic side being only $36.36 \%$ of its maximum activity at $\mathrm{pH} 4.0$. MTGase was stable at $\mathrm{pH} 6.5$ for one hour. At $\mathrm{pH}$ 5.0 the retained activity was about $50 \%$ of the initial activity. The activity decreased greatly below pH 5.0 and above 8.5 (Table 2).

Table 2: Effect of $\mathrm{pH}$ on MTGase activity produced from Streptomyces diastaticus.

\begin{tabular}{|c|c|c|}
\hline $\mathrm{pH}$ & Relative activity (\%) & Stability (\%) \\
\hline 4.0 & 36.36 & 37.70 \\
\hline 4.5 & 48.48 & 50.82 \\
\hline 5.0 & 48.48 & 65.57 \\
\hline 5.5 & 68.18 & 78.69 \\
\hline 6.0 & 86.36 & 100.00 \\
\hline 6.5 & 100.00 & 90.16 \\
\hline 7.0 & 81.82 & 81.97 \\
\hline 7.5 & 48.48 & 55.74 \\
\hline 8.0 & 18.18 & 44.26 \\
\hline 8.5 & 9.09 & 29.51 \\
\hline
\end{tabular}

These results are in agreement with other authors (Cui et al., 2007) who reported that, the enzyme exhibited optimum activity in a range of $\mathrm{pH}$ 6.0- 7.0. Also, they declared that, the purified MTGase was stable within a wide range of $\mathrm{pH} 5.0-8.0$ at $10^{\circ} \mathrm{C}$. The enzyme was stable at $\mathrm{pH} 5.0-7.0$ after $30 \mathrm{~min}$ of incubation at $37^{\circ} \mathrm{C}$ and about $50 \%$ activity was retained at $\mathrm{pH}$ 8.0.The activity decreases greatly outside this $\mathrm{pH}$ range. 


\section{Attest the cross-linking effect of the prepared enzyme:-}

The attest of the occurrence of cross-linking and/ or its effect have to be proofed prior to its application in food. The cereal products mainly bread is one of the common applications of MTGase in food industry. So, the cross-linking effect will be tested through cross-linking of wheat dough prepared for Shamy bread making. The amount of the enzyme used was 100 enzyme units per $500 \mathrm{~g}$ of the flour used. The Shamy bread was prepared as described in the materials and methods section.

The free amino groups which representing the direct cross-linking by forming a new iso-peptide bonds and the free thiol groups which indicate the indirect effect refer to the oxidation of free sulfhydryl group and formation of disulphide bonds were investigated. The changes of the free amino and thiol groups content will be used as a tool for tracing the cross-linking occurred.

The results indicated that the enzyme have a cross-linking effects towards the free amino and thiol groups .These results are in agreement with those reported by all authors used MTGase (Gujral and Rosell, 2004 ; Ahn et al., 2005).

\section{Tracing the effect of MTGase in dough prepared from blends of wheat and corn Flours:-}

The following experiments were carried out to investigate the possibility of incorporating corn flour into wheat flour at higher levels for making Shamy bread with the aid of MTGase cross-linking. Corn flour was mixed with wheat flour at levels of 10, 20,30,40, and $50 \%$ of the weight of wheat flour.

\section{Free amino groups:-}

The data in Table (3) revealed that the free amino groups of the dough. The results indicated that the enzyme have a cross- linking effects towards the free amino and thiol groups of wheat dough. The free amino groups of the wheat dough were $0.538 \mu \mathrm{M} / \mathrm{mg}$ flour without adding the enzyme. It decreased to $0.378 \mu \mathrm{M} / \mathrm{mg}$ flour when treated with the enzyme; the percent of reduction was 29.74. Mixing corn flour with wheat flour decreased the free amino groups of the resulted dough. It decreased to $0.356 \mu \mathrm{M} / \mathrm{mg}$ flour, in dough containing $10 \%$ corn flour and treated with the enzyme. Increasing the level of corn flour to $30 \%$ caused a decrease in the free amino group to $0.248 \mu \mathrm{M} / \mathrm{mg}$ flour with reduction of $34.39 \%$. The cross-linking effect was 0.142 and $0.130 \mu \mathrm{M} / \mathrm{mg}$ flour in the blends containing of $10 \%$ and $30 \%$ corn flour, respectively. When the level of corn flour increased to $50 \%$, a slight decrease in the crosslinking effect was observed. Generally increasing the corn wheat to $30 \%$ did not affect or have a slight positive effect on the enzyme activity.

Table 3:- Effect of prepared MTGase on the free amino groups in dough of wheat and corn flour blends

\begin{tabular}{|c|c|c|c|c|}
\hline \multirow[t]{2}{*}{ Flour blends } & \multirow[t]{2}{*}{ Control } & \multicolumn{3}{|c|}{ Free amino groups ( $\mu \mathrm{M} / \mathrm{mg}$ flour $)$} \\
\hline & & $\begin{array}{l}\text { After treatment } \\
\text { "Residual" }\end{array}$ & $\begin{array}{l}\text { Cross-linking } \\
\text { effect }\end{array}$ & $\begin{array}{l}\text { Reduction } \\
(\%)\end{array}$ \\
\hline Wheat flour $100 \%$ & 0.538 & 0.378 & 0.160 & 29.74 \\
\hline Wheat flour $90 \%+$ Corn flour $10 \%$ & 0.498 & 0.356 & 0.142 & 28.51 \\
\hline Wheat flour $80 \%+$ Corn flour $20 \%$ & 0.414 & 0.288 & 0.126 & 30.43 \\
\hline Wheat flour $70 \%+$ Corn flour $30 \%$ & 0.378 & 0.248 & 0.130 & 34.39 \\
\hline Wheat flour $60 \%+$ Corn flour $40 \%$ & 0.288 & 0.208 & 0.080 & 27.78 \\
\hline Wheat flour $50 \%+$ Corn flour $50 \%$ & 0.258 & 0.184 & 0.074 & 28.68 \\
\hline
\end{tabular}

Gujral and Rosell (2004) reported that when rice flour was treated with different concentrations of MTGase, a progressive decrease in the amount of free amino groups was observed on addition of MTGase up to $1.0 \%$. Beyond that concentration no significant differences in the amount of free amino groups were detected. This could be due to the disappearance of the lysine groups exposed to the enzyme effect. Ahn et al. (2005) indicated that, the amount of free amino groups in TGase-treated wheat, barley and soy flours and their blends were decreased with TGase treatment.

\section{Free thiol groups:-}

The data in Table (4) indicated that, the free thiol groups of the control samples (without enzyme) in the dough of wheat and corn flour blends decreased with increasing the percentage of corn flour. 
Table 4:- Effect of prepared MTGase on the free thiol groups in dough of wheat and corn flour blends

\begin{tabular}{|l|l|l|l|l|}
\hline \multicolumn{1}{|c|}{ Flour blends } & \multirow{2}{*}{ Control } & \multicolumn{3}{c|}{ Free thiol groups $(\mu \mathrm{M} / \mathrm{g}$ flour $)$} \\
\cline { 3 - 5 } & & \multicolumn{1}{|c|}{ After treatment } & Cross-linking effect & Reduction \% \\
\hline Wheat flour 100\% & 11.222 & 10.342 & 0.88 & 7.849 \\
\hline Wheat flour 90\% + Corn flour 10\% & 10.861 & 10.008 & 0.853 & 7.854 \\
\hline Wheat flour 80\% + Corn flour 20\% & 9.411 & 8.604 & 0.807 & 8.575 \\
\hline Wheat flour 70\% + Corn flour 30\% & 9.103 & 8.626 & 0.477 & 5.240 \\
\hline Wheat flour 60\% + Corn flour 40\% & 8.612 & 8.211 & 0.401 & 4.656 \\
\hline Wheat flour 50\% + Corn flour 50\% & 8.114 & 7.834 & 0.28 & 3.573 \\
\hline
\end{tabular}

In general, increasing the percentage of corn flour in the blends treated with MTGase decreased the free thiol groups. The free thiol groups of the wheat dough (without enzyme) were $11.222 \mu \mathrm{M} / \mathrm{g}$ flour, it decreased to 10.342 $\mu \mathrm{M} / \mathrm{g}$ flour when treated with the enzyme, with reduction of $7.849 \%$. The free thiol groups of the dough (without enzyme) contain $10 \%$ corn flour was $10.861 \mu \mathrm{M} / \mathrm{g}$ flour, it decreased to $10.008 \mu \mathrm{M} / \mathrm{g}$ flour when treated with the enzyme. When the levels of corn flour increased to $30 \%$ the free thiol groups decreased from $9.103 \mu \mathrm{M} / \mathrm{g}$ flour in the untreated sample (control) to $8.626 \mu \mathrm{M} / \mathrm{g}$ flour in the sample treated with the enzyme. Increasing the level of corn flour caused a gradually decrease in the free thiol groups. At a level of 50\% corn flour the cross-linking was $0.28 \mu \mathrm{M} / \mathrm{g}$ flour with a reduction reached $3.573 \%$ in the sample treated with the enzyme.

Gujral and Rosell (2004) declared that, there was a significant decrease in the free thiol groups content of rice flour treated with TGase. The decrease in thiol groups was more significant at a TGase concentration of $0.5 \%$ compared with 1 and $1.5 \%$. The reduction in thiol groups concentration suggests the formation of disulphide bonds is most likely favored by the proximity of the cross-linked polypeptide chains.

Ahn et al. (2005) mentioned that, significant decrease in the number of free thiol groups of the blended samples (wheat, barley and soy flour) up on TGase treatment. Sulfur-containing amino acids may come close to each other during the TGase reactions leading to the formation of disulfide bonds via oxidation.

Ap et al. (2011) reported that the enzyme modified chemical and functional properties of glutenins fraction of proteins, improving dough strength and bread volume.

\section{Application of MTGase in Shamy bread using wheat and corn flour blends:-}

Wheat flour is the main flour used for production of bread and many other bakery products. Wheat flour contains proteins, mainly gluten which is the dominant proteins that characterize dough properties and play an important part in the quality of bread. Disulfide bridges between gluten proteins strengthen the gluten network, which is beneficial for the quality of the baked loaf (Kaufmann et al., 1986).

Corn flour is one of the most valuable cereal flours from a nutritional point of view. However, corn flour is unable to hold gas produced during fermentation for baked products. The properties of corn flour are very different from wheat flour this is because of the absence of gluten.

The previous results of tracing the cross-linking effect revealed from the free amino and thiol groups (Tables 3 and 4) indicated that the maximum effect was observed when using a flour blend contains $70 \%$ wheat and $30 \%$ corn flour. So this blend was used for making Shamy bread as indicated in the materials and methods section.

Figure (1) shows a complete and cross section of the prepared bread. The figure indicated that, the prepared loaf from the dough treated with the enzyme have a higher volume with pronounced improvement in the general appearance and quality than that when no enzyme was used. 

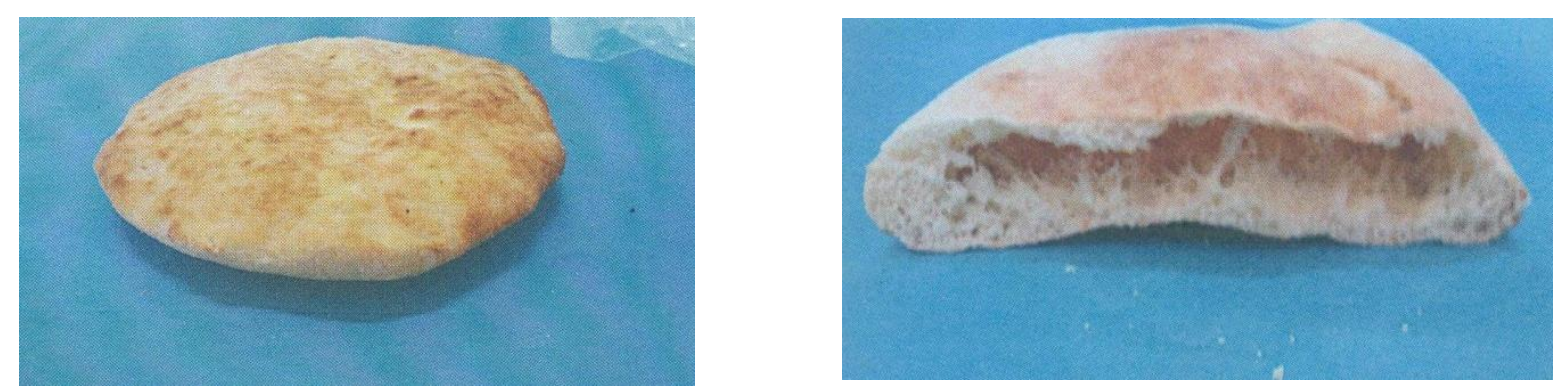

\section{With MTGase}
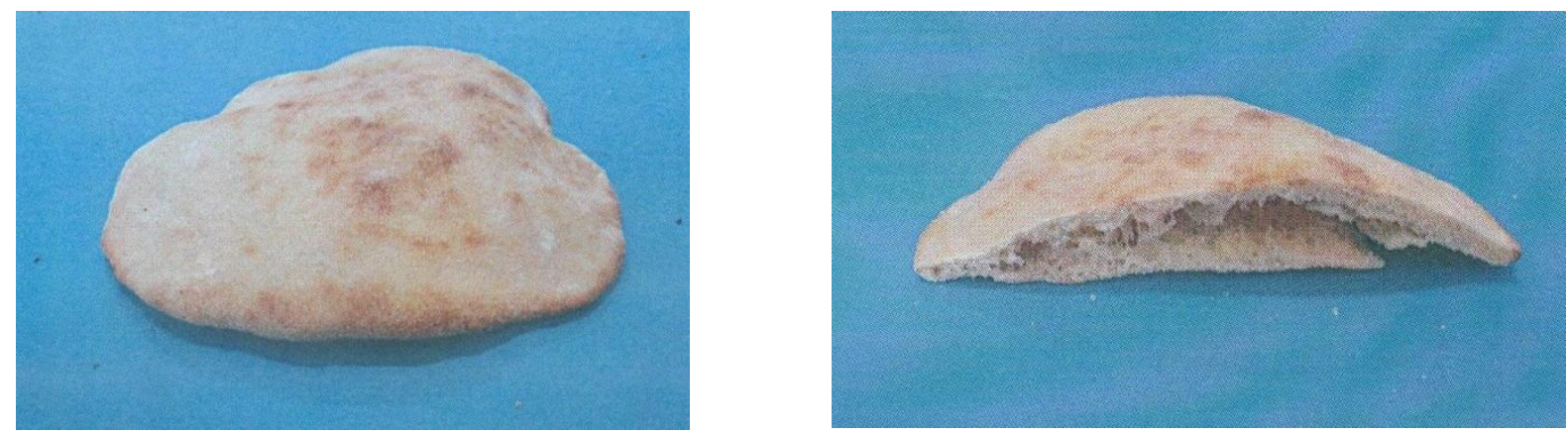

Without MTGase

Figure 1:- Baking performance of dough prepared from $70 \%$ wheat flour and $30 \%$ corn flour with and without the purified enzyme

De Jong and Koppelman (2002) stated that, articles describing the use of TGase in cross-linking of proteins are mostly focused on one single type of protein. The cross-linking reaction can however also be applied to the glutamines and lysine of two different types of proteins. By coupling two proteins with different structures, totally new functionalities can be created.

Basman et al. (2003) reported that, bread from TGase-treated samples prepared from different blends of wheat and barley flours had higher loaf volumes and better crumb and crust characteristics, and were apparently softer than those from untreated samples up 30\% barely flour supplementation level. The increases in loaf volumes of TGasetreated samples might be the result of TGase transforming weak gluten into a strong one due to TG-catalyzed crosslinking reactions between and within wheat and barley proteins.

Gujral and Rosell (2004) reported that, the specific volume of rice bread which treated with MTGase increased by increasing the concentration of MTGase up to $1 \%$, but negative effects was observed at higher concentrations. They attributed this behavior to the ability of the TGase to transform weak gluten into a strong one and suggest that at high TGase concentrations excessive cross-linking produced over-strong dough. Ap et al. (2011) reported that the enzyme modified chemical and functional properties of glutenins fraction of proteins, improving dough strength and bread volume.

\section{Conclusion:-}

It can be concluded that the prepared enzyme have a cross-linking effects towards the free amino and thiol groups. Also, it is possible to produce Shamy bread with a good quality from a blend of wheat flour mixed with a high level of corn flour reached to $30 \%$ with the aid of the prepared enzyme. This is due to the cross-linking effect of the enzyme. The maximum level of corn flour which used previously was $20 \%$ only without using the enzyme.

\section{References:-}

1. Ahn H.J., Kim J.H., and Ng P.K.W. (2005). Functional and thermal properties of wheat barley, and soy flours and their blends treated with a microbial transglutaminase. Journal of Food Science 70: 380- 386. 
2. Ap E., Seravalli G., Lguti A.A., Ap I., and Filho F.F. (2011). Effects of application of transglutaminase in wheat proteins during the production of bread. Procedia Food Science 1: 935- 942.

3. Cui L., Du G., Zhang D., Liu H., and Chen J. (2007). Purification and characterization of transglutaminase from a newly isolated Streptomyces hygroscopicus. Food Chemistry 105: 612- 618.

4. Dube M., Schäfer C., Neidhart S., and Carle R. (2007). Texturisation and modification of vegetable proteins for food applications using microbial transglutaminase. European Food Research and Technology 225: 287299.

5. Eshra D.H., El-Iraki S.M., and Abo Bakr T.M. (2015). Isolation and identification of actinomycetes transglutaminase producing strain. International Journal of Current Science 18: E 76- 88

6. Gerrard J.A., Fayle S.E., Brown P.A., Sutton K.H., Simmons L., and Rasiah I. (2001). Effect of microbial transglutaminase on the wheat proteins of bread and croissant dough. Journal of Food Science 66: 781-786.

7. Gujral H.S., and Rosell C.M. (2004). Functionality of rice flour modified with microbial transglutaminase. Journal of Cereal Science 39: 225- 230.

8. Ho M.L., Leu S.Z., Hsieh J.F., and Jiang S.T. (2000). Technical approach to simplify the purification method and characterization of microbial transglutaminase produced from Streptoverticillium ladakanum. Journal of Food Science 65: 76-80.

9. Kuraishi C., Yamazaki K., and Susa Y. (2001). Transglutaminase: its utilization in the food industry. Food Reviews International 17: 221- 246.

10. Larré C., Denery Papini S., Popineau Y., Deshayes C., Desserme C., and Lefebvre J. (2000). Biochemical analysis and rheological properties of gluten modified by transglutaminase. Cereal Chemistry 77: 121- 127.

11. Macedo J.A., Sette L.D., and Sato H.H. (2007). Optimization of medium composition for transglutaminase production by a Brazilian soil Streptomyces sp. Electronic Journal of Biotechnology 10: 618-626.

12. Nielsen P.M. (1995). Reactions and potential industrial applications of transglutaminase. Food Biotechnology 9: $119-156$.

13. Nielsen P.M., Petersen D., and Dambmann C. (2001). Improved method for determining food protein degree of hydrolysis. Journal of Food Science 66: 642-646.

14. Nonaka M., MatsuuraY., Nakano K., and Motoki M. (1997). Improvement of the pH-solubility profile of sodium caseinate by using $\mathrm{Ca}^{2+}$ independent microbial transglutaminase with gelatin. Food Hydrocolloids 11: 347- 349 .

15. Rao U.J.S.P. , Vatsala C.N., and Rao P.H. (2002). Changes in protein characteristics during the processing of wheat into flakes. European Food Research and Technology 215: 322-326.

16. Umezawa Y., Ohtsuka T., Yokoyama K., and Nio N. (2002). Comparison of enzymatic properties of microbial transglutaminase from Streptomyces sp . Food Science and Technology Research 8:113- 118.

17. Wang F., Huang W., Rayas-Duarte P., Wang H., and Zou Q. (2013). Baking characteristics of Chifon cake as influenced by microbial Transglutaminase. Cereal Chemistry 90: 463-468.

18. Yokoyama K. , and Kikuchi N.N.Y. (2004). Properties and applications of microbial transglutaminase. Applied Microbiology and Biotechnology 64: 447- 454.

19. Zhu Y., Rinzema A., Tramper J., and Bol J. (1995). Microbial transglutaminase- a review of its production and application in food processing. Applied Microbiology and Biotechnology 44: 227-282. 